\title{
ПРО ФУНКЦІОНАЛЬНЕ ЗОНУВАННЯ ТЕРИТОРІЙ НАЦІОНАЛЬНИХ ПРИРОДНИХ ПАРКІВ СВІТУ ТА УКРАЇНИ
}

\section{Гетьман B. I.}

\section{ВСТУП}

Основним розділом проектів організації природно-заповідних територій та об’єктів України, охорони, відтворення і використання їх природних комплексів $є$ функціональне зонування, яке розробляється на об'єктивній науковій основі і водночас є однією з важливих проблем заповідної справи.

Функціональне зонування здійснюється 3 метою практичної реалізації основних функцій природно-заповідних територій та об'єктів: збереження цінних природних та історико-культурних комплексів і об'єктів; створення умов для організованого туризму, інших видів і форм рекреації (рекреаційної діяльності) в природних умовах 3 додержанням заповідного (диференційованого) режиму; проведення наукових досліджень ландшафтних (ЛК) комплексів та їх змін в умовах рекреаційного використання, розроблення відповідних наукових рекомендацій (охорона і використання природних ресурсів); проведення екологічної освітньо-виховної роботи; сприяння соціальноекономічному розвитку регіону (місцевості).

Під функціональним зонуванням розуміють розділення природнозаповідних територій та об'єктів на ділянки (зони) з різними режимами збереження, відтворення і використання природних комплексів ${ }^{1}$.

Однак досі для зазначених територій та об'єктів не розроблені загальні теоретичні і методичні питання цього зонування, не існує єдиної моделі його структури. Нині жодний міжнародний чи вітчизняний документ не дає критеріїв зонування.

В Україні існує певний досвід проведення поліфункціонального зонування територій національних природних парків (НПП). У цьому відношенні заслуговують на увагу наукові доробки провідних вчених України С.Ю. Поповича (2007), Т.Ф. Панченко (2015), П.Г. Шищенка (1988) та інших.

Але треба зазначити, що в літературних джерелах ще відсутні достатньо науково обгрунтовані методичні рекомендації щодо виділення функціональних зон, їх оптимальних площ, конфігурацій,

1 Попович С.Ю. Природно-заповідна справа : навчальний посібник. Київ : Арістей, 2007. 480 с. 
допустимих антропогенних (рекреаційних) навантажень на ділянки природно-заповідних територій та об'єктів.

Попередньо зазначимо, що функціональне зонування територій НПП України проводиться за вільним типом: загальний рисунок мозаїчний, ділянки кожної зони представлені декількома контурами тобто воно має кластерний характер. Однак щодо цього питання і досі тривають дискусії.

Метою дослідження $€$ показати актуальність пошуку нових (креативних) шляхів і форм здійснення функціонального зонування територій НПП України задля оптимального збереження та охорони заповідного біотичного і ландшафтного різноманіття.

Під час написання статті автор дотримувався чотирьох рівнів методології науки: філософсько-світоглядного, загальнонаукового, конкретно-наукового (методи ландшафтознавства) i техніки досліджень. Так, для доведення своїх положень було використано аналітичний методологічний прийом (метод аналізу). Також застосовано низку інших методів, зокрема загальнонаукові (логічні) синтезу, абстракції, індукції і дедукції; конкретно-наукові (методи ландшафтознавства, передусім спостереження, історико-географічний, порівняльно-географічний та інші).

\section{1. Тлумачення поняття національного парку у світі і національного природного парку в Україні}

Що розуміють під національним парком у світі і національним природним парком в Україні? Термін «національний парк» уперше 3'явився у Сполучених Штатах Америки, де 1 березня 1872 р. спеціальним декретом вісімнадцятого президента Улісса Гранта був створений «для користі і блага нації» перший у світі Йєллоустонський національний парк («Країна чудес») площею 899104 га. У 1890 р. у США організовують два нових НП - «Джосемайт» і відомий широкому загалу - «Секвойя». На цей час у США створено 58 національних парків з 359 природно-заповідних територій найвищої категорії. В Свропі перший національний парк створений у Голландії у 1905 р., потім у Швеції («Сарек», 1909 р.), Швейцарії (1914р.). Зараз у світі існує більш як 2,5 тис. національних парків.

За єдиним природоохоронним визначенням, прийнятим на Х Генеральній Асамблеї Міжнародної спілки охорони природи і природних ресурсів (МCOП, IUCN), що проходила в Нью-Делі в листопаді 1969 р., національний парк (НП) - це достатньо велика територія (необхідна для здійснення процесів саморегуляції екологічних систем), яка включає одну або кілька екосистем, мало змінених або не змінених експлуатацією та поселенням людини, відзначається різноманітними типами ландшафтів, багатством рослинного i тваринного світу, а також різноманітністю 
геоморфологічних систем, особливо цінних 3 наукової, освітньої, виховної та рекреаційної точок зору, або яка характеризується природними пейзажами високої естетичної цінності ${ }^{2}$.

Ще раніше, у 1962 р., на I Всесвітньому конгресі з національних парків, що відбувся у Сіетлі (США), як окрема категорія охоронних об'єктів був виділений природний парк. Основна функція природних парків полягає в організації умов для рекреації, туризму. В Україні природному парку відповідає регіональний ландшафтний парк.

У національних парках (II категорія за класифікацією МСОП) охорона природи частково поєднується 3 рекреацією, тобто відпочинком людей в природному, мало зміненому середовищі. Це означає, що вони виконують передусім природоохоронну, а також рекреаційну функцію. В багатьох НП під рекреаційне використання відводиться до 5-10\% території, однак природоохоронні задачі переважають над рекреаційними (хоча скрізь в обгрунтованій мірі допускається екотуризм.). На відміну від заповідників, національні парки не можуть бути повністю закритими для відвідування ${ }^{3}$.

Тобто основним режимом на території НП, включаючи землі, які на час включення були неприродними, є режим невтручання. Не менше $75 \%$ площі вважаються суворо охоронними без регулювальних заходів і порушень природної сукцесії. Антропогенні ландшафти там займають незначну площу.

На другій світовій конференції щодо розвитку національних парків, яка відбулася у 1972 р. в Єллоустонському НП, було висунуто цілий ряд вимог: територія національного парку повинна підлягати функціональному зонуванню з чітким використанням кожної із зон, обмежити або повністю заборонити користування автотранспортом, використовувати менш загрозливий вид пересування, ретельно обгрунтувати необхідність будівництва мережі доріг, зменшувати інтенсивність потоків рекреантів, пропонуючи їм паліативні природні території поза межами НП.

У наукових колах країн, зокрема пострадянського простору, незмінними залишаються дві точки зору (підходи, моделі) щодо пріоритетних функцій національного парку. Перша - національний парк є природоохоронним об'єктом, наближеним за статусом до заповідника (А. Банніков, В. Криницький). Друга - національний парк $\epsilon$ рекреачійним об'єктом з підвищеними вимогами до охорони природи (М. Реймерс, Ф. Штільмарк) ${ }^{4}$.

2 Заповідна справа в Україні / Під загальною редакцією М.Д. Гродзинського і М.П. Стеценка. Київ : Географіка, 2003. 306 с.

Гетьман B.I. Національні природні парки України. Київ : Редакція газет природничо-математичного циклу. 2012 (Бібліотека «Шкільного світу»). 2012. 128 с.

4 Забелина Н.М. Национальный парк. Москва : Мысль, 1987. 175 с. 
В Україні термін «національні природні парки» вперше офіційно 3'явився 3 прийняттям Закону України «Про природно-заповідний фонд України» від 16 червня 1992 р. До цього існувала назва «державний природний національний парк», яка була затверджена Постановою Ради Міністрів Української РСР «Про класифікацію і мережу територій та об’єктів природно-заповідного фонду Української РСР» від 22 липня 1983 р. № 311. 31972 р. фігурувала назва «державний природний парк» відповідно до затвердженої Урядом «Класифікації заповідних та інших територій УРСР, що охороняються державою».

Відповідно до ст. 20 вище зазначеного Закону України національні природні парки - це природоохоронні рекреаційні, культурно-освітні, науково-дослідні установи, що створюються 3 метою збереження, відтворення та ефективного використання природних комплексів та об'єктів, які мають особливу природоохоронну, оздоровчу, історикокультурну, наукову, освітню та естетичну цінність.

В Україні створено вже 52 національних природних парків. Перший - Карпатський НПП оголошено Постановою Ради Міністрів Української РСР від 3 червня 1980 р. (спочатку як державний природний, пізніше - державний природний національний). Однак перший власне Український національний парк було створено в 30-ті роки минулого століття митрополитом Андрієм Шептицьким. Зараз на його місці знаходиться ландшафтний заказник загальнодержавного значення «Грофа» площею 2 533, 8 га (Івано-Франківська обл., Рожнятівський р-н) ${ }^{5}$.

\section{2. Функціональне зонування території національних}

\section{природних парків як просторова диференціація їх функцій}

Практичний досвід створення та діяльності НПП України переконує, що проблема планування їх території має принципово важливе значення. Ї̈̈ практичне вирішення є основною передумовою забезпечення врівноваженого і безконфліктного функціонування цих поліфункціональних природно-заповідних установ.

Основним способом «самореалізації» НПП $є$ функціональне зонування його території. Воно здійснюється задля створення необхідних умов виконання національним природним парком функцій, часто суперечливих: природоохоронних (збереження біорізноманіття території забезпечення екологічно збалансованого природокористування та інше) та рекреаційна.

Функціональне зонування території НПП не що інше, як чітка диференціація у просторі його функцій. Воно може розглядатися як

5 Природно-заповідний фонд України загальнодержавного значення. Довідник. Київ : Омега-Л, 1999. 240 с. 
процес теоретичного пізнання та практичної реалізації існуючої інформації про парк.

Результатом функціонального зонування території НПП виступає схема, чи картосхема, як наочне відображення просторових функцій, які ця територія має виконувати. На цій схемі виділяють територіальні ділянки (функціональні зони), які різняться за функціями та цілями охорони, а отже, - охоронними режимами і формами практичної діяльності в їх межах ${ }^{6}$.

Функціональне зонування території НПП також можна розглядати i як_цільову просторово-функціональну модель охоронної території. Відповідно, практична діяльність 3 іiі охороні територіально диференційована за виділеними функціональними зонами. Воно $\epsilon$ шляхом до реалізації цієї моделі.

Склад функціональних зон і значеннєві показники їх територій у різних (вітчизняних і зарубіжних) національних парків відрізняються. Розглянемо спочатку схему функціонального зонування, прийняту для територій НПП України.

Відповідно до ст. 21 Закону України «Про природно-заповідний фонд України» з метою забезпечення виконання НПП покладеного на них завдання щодо створення умов для організованого туризму, відпочинку та інших видів рекреаційної діяльності в природних умовах 3 додержанням режиму охорони заповідних ЛК i об'єктів на їх території виділяють зони регульованої і стаціонарної рекреації․ Крім зон рекреації, також виділяють заповідну і господарську зони. Назви зон визначаються за їх основною функцією. Зона може поділятися на підзони. Межі зон проводяться за природними лініями (контурами) басейни річок, гірські хребти, береги водойм, лісові виділи тощо.

У зоні регульованої рекреації дозволяється влаштування та відповідне обладнання туристських маршрутів і екологічних стежок; тут забороняється діяльність, яка може негативно вплинути на стан природних ландшафтів розміщеної по сусідству заповідної зони.

Площа зони регульованої рекреації може становити 25-55\% від загальної території парку рекреаційного типу і 30-60\% природоохоронного типу.

Зона стаціонарної рекреачї призначена для розміщення готелів, мотелів, кемпінгів, інших об'єктів обслуговування відвідувачів парку. Площа цієї зони орієнтовно становить 5-10\% в умовах обмеженого рекреаційного використання i $10-20 \%$ - активного рекреаційного

\footnotetext{
6 Заповідна справа в Україні / Під загальною редакцією М.Д. Гродзинського і М.П. Стеценка. Київ : Географіка, 2003. 306 с.

7 Методичні рекомендації щодо складу та змісту проекту організації території національного природного парку, охорони, відтворення та рекреаційного використання його природних комплексів і об'єктів. Київ : Центр екомоніторингу України, 2005. 95 с.
} 
використання території парку. Екотуризм у цій зоні може здійснюватися за екстенсивним чи інтенсивним планом на відповідних територіях (підзонах). Можуть виділятися підзони інтенсивної та екстенсивної рекреації. Співвідношення площ цих територій знаходиться відповідно в межах 1:2.

На територіях інтенсивної рекреаиії (враховуючи зарубіжний досвід) на базі розміщених тут рекреаційних закладів можуть створюватися:

- гірськолижні комплекси, до складу яких входять лижні поля, траси, канатні підйомники, чи «витяги» (крісельні, бугельні), трампліни, льодові стадіони тощо;

- рекреаційно-акваторіальні комплекси (аквателі), до складу яких входять пляжі, зупинки для яхт і човнів, елінгі, готелі та об'єкти обслуговування.

На територіях екстенсивної рекреаиії з метою огляду місцевості та відпочинку головним чином створюються туристські маршрути, екскурсійні та прогулянкові еколого-освітні стежки (лінійні, радіальні, кільцеві), обладнуються місця для ночівлі (хижі, шале, бівуачні стоянки) тощо. У цій підзоні на спеціально виділених та відповідно облаштованих ділянках дозволяється любительське та спортивне рибальство, збирання грибів, дикорослих плодів і ягід, фотополювання («тихе полювання») під екологічним контролем працівників (рейнджерів) служби державної охорони національних природних парків.

Заповідна зона призначена для охорони та відновлення найбільш цінних природних комплексів, режим якої визначається відповідно до вимог, встановлених для природних заповідників. Величина заповідної зони національних парків у світі визначається за міжнародними стандартами. В Україні ії площа може становити 20-30\% (20\% - для зони лісостепу, 10\% - для степу) площі території НПП (якщо він має розвинуту рекреаційну функцію) i 30-50 (60) \% (якщо він має розвинуту природоохоронну функцію). МСОП пропонує для національних парків мінімальну площу заповідної «території-ядра» до 1000 га $^{8}$.

Заповідна зона НПП, розміщених у відносно екологічно стабільних регіонах та на мало порушених природних територіях гірських (високогірних, гірсько-лісових), рівнинних (лісових, водно-болотних, зандрових, моренно-зандрових, лиманних, солончакових, плавневих) ландшафтів та на морських акваторіях, має становити більше третини від усієї площі парку.

Заповідна зона НПП, розміщених в екологічно нестабільних регіонах та на середньо порушених природних територіях (акваторіях)

8 Гетьман В.І. Національні природні парки України. Київ : Редакція газет природничо-математичного циклу. 2012. (Бібліотека «Шкільного світу»). 128 с. 
лісостепових, лучно-лісових, заплавних, прісноводних ландшафтів, має становити більше $20 \%$ площі парку.

Заповідна зона НПП, розміщених в екологічно мало стабільних регіонах та на сильно порушених природних територіях степових, лучних, байрачних, піщано-черепашкових, скельних, подових тощо ландшафтів, має становити $15 \%$ від усієї площі парку або $10 \%$ від площі його природних ділянок'.

У господарській зоні ведеться традиційна господарська діяльність 3 дотриманням вимог щодо охорони природного навколишнього середовища. Площа цієї зони залежно від ії складу може становити 5$25 \%$ території парку.

Для прикладу і підтвердження вищесказаному пропонуємо відносно непогано виконане функціональне зонування території НПП «Синевир» в Українських Карпатах (рис. 1) ${ }^{10}$.

За непогано розробленого i законодавчо затвердженого функціонального зонування НПП України треба, однак, сказати, що лише незначна їx частина відповідає II категорії міжнародної класифікації - національний парк (охорона екосистем і рекреація).

Так, площа, зайнята антропогенними ландшафтами у вітчизняних НПП, занадто велика (на що є суб'єктивні причини, з огляду на значну розораність країни) і має доволі дивні розходження між парками - від $1 \%$ в Азово-Сиваському НПП до 95\% у «Подільських Товтрах». Те, що в НПП «Подільські Товтри» на господарську зону приходиться такий великий відсоток його території, а на заповідну менше $1 \%(0,61 \%)$, говорить про безглуздість у нашому «королівстві». Одне тільки радує це найбільший (якщо не рахувати такого на о. Гренландія площею 70 млн га) національний парк Свропи (261 316 га) $)^{11}$.

Загалом антропогенні ландшафти займають до половини (і більше) території наших національних парків. Для порівняння скажемо, що в Польщі ця величина коливається від $1 \%$ до $20 \%$ і становить у середньому $4 \%{ }^{12}$.

В Україні існує практика (функціонального зонування) виділяти землі, вилучені з господарського користування, і землі, надані НПП у постійне користування (хоча у вищезазначеному Законі такого «феномена» чітко ніде не прописано). Це, мабуть, було продиктовано прагненням збільшити площу природно-заповідного фонду України i «дотягнутись» до європейського зразка (10-15\% від площі країни).

9 Попович С.Ю. Природно-заповідна справа : навчальний посібник. Київ : Арістей, 2007. 480 с.

${ }_{10}$ Попович С.Ю. Природно-заповідна справа : навчальний посібник. Київ : Арістей, 2007. 480 c.

11 Заповідники і національні природні парки України. Київ : Вища школа, 1999. $232 \mathrm{c}$.

${ }^{12}$ Национальные парки в Польше. Варшава : Шевелье, 1989. 16 с. 


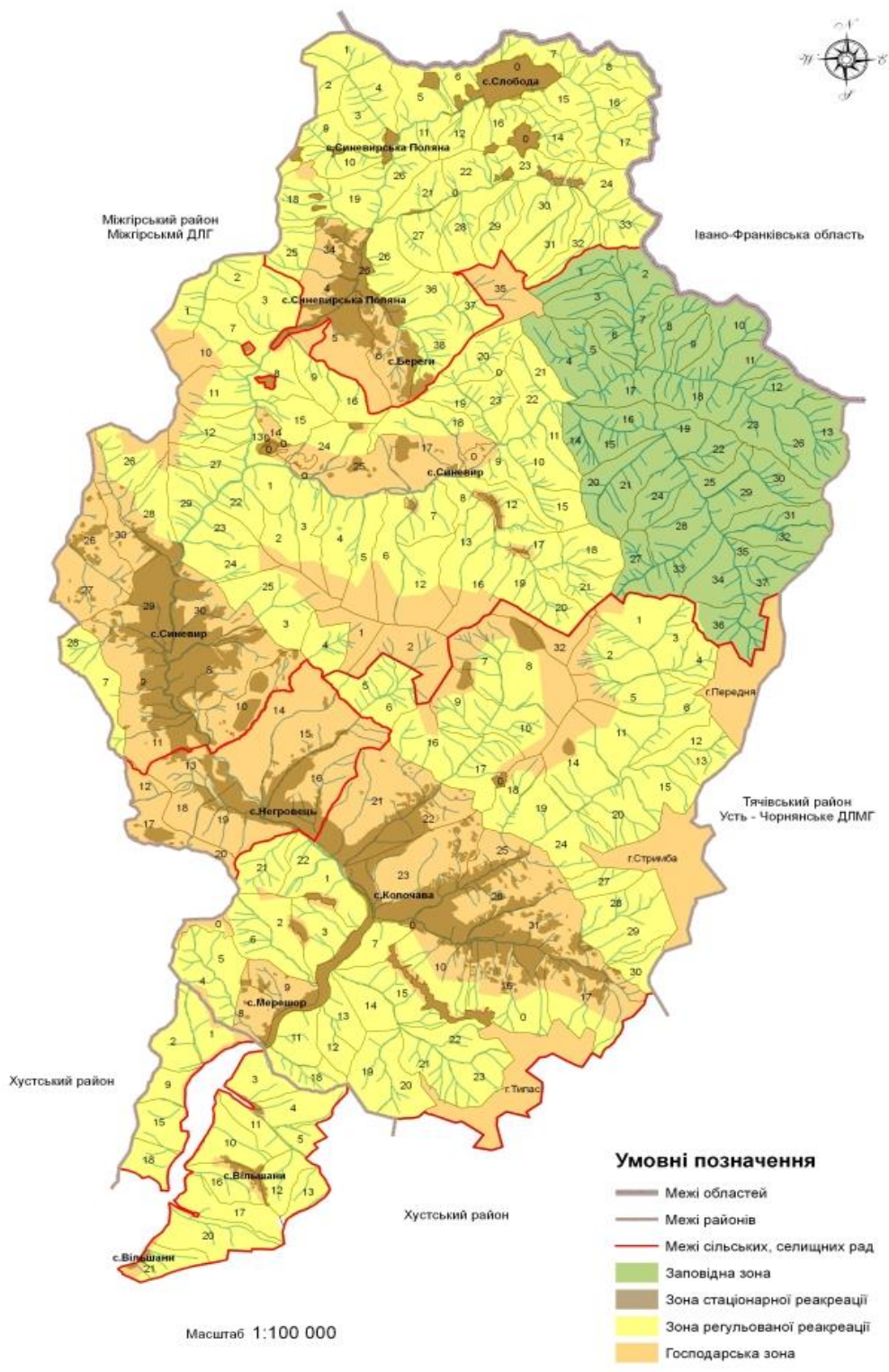

Рис. 1. Карта функціонального зонування НПП «Синевир» 
Також частка земель, що знаходяться у постійному землекористуванні НПП України, невелика і складає у середньому $1 / 4$ частину їх загальної площі, а по установах вона міняється з напрочуд дивною амплітудою - від $1 \%$ у тих же «Подільських Товтрах» (крутосхили річкової долини Дністра шириною 100 м і протяжністю 120 км, які практично не можна використати) до 100\% в АзовоСиваському НПП.

У Росії, наприклад, більшість національних парків належить до II категорії МСОП і порівняно з нашими вони мають значно суворіший режим і більшу частину земель у власному користуванні (83\%) ${ }^{13}$.

Цікаві особливості функціонального зонування мають національні парки Німеччини. Так, наприклад, перший у цій країні національний парк «Баварський ліс» має заповідну зону, три зони розвитку лісів, буферну та зону рекреації, яка включає дві підзони: інтенсивної рекреації (включаючи сектори: історичних об'єктів, зоологічний, розважальний) та пішохідного туризму й альпінізму; основну частину парку займає резерват - до 70\% загальної площі його території.

Йєллоустонський національний парк у США також має цікавий склад функціональних зон (з пріоритетом охоронюваних територій): території, доступні для автомобілістів - 25\% загальної площі парку; території, не доступні для автомобілістів - 75\% (включаючи підзони: охоронюваного ландшафту $-50 \%$, найпростішого облаштування ділянок для відпочинку $-25 \%)^{14}$.

Крім зазначених, є й інші особливості функціонального зонування національних парків. Наприклад, виділення значних за площею спортивно-рекреаційних зон - до 65\% території парку (Канада); охоронних (буферних) зон, які в 5 разів і більше перевищують площу самих національних парків (Франція); фауністичних зон туризму, мисливства (країни Африки); гірських фауністичних зон 3 обмеженнями для туристів: заборона магнітофонів, транзисторних радіоприймачів, яскравого одягу тощо (Італія) ${ }^{15}$.

\section{3. Планувальна організація територій національних парків}

На особливостях функціонального зонування національних парків, а також на основі територіальної конфігурації місць ландшафту (лісові масиви, системи озер, групи островів, дельти річок, узбережжя крупних водойм) базується ї планувальна організачія. Вона складається 3 планувальної структури і функціонального зонування території. На формування планувальної організації суттєво впливають такі типи іiі

13 Андрієнко Т.Л. Система категорій природно-заповідного фонду України та питання її оптимізації / Т.Л. Андрієнко, В.А. Онищенко, М.Л. Клєстов, О.І. Прядко, Р.Я. Арап. Київ : Фітосоціоцентр, 2001. 60 с.

14 Панченко Т.Ф. Ландшафтно-рекреаційне планування природно-заповідних територій [Монографія]. Київ : Логос, 2015. 176 с.

$$
\text { Архитектурно-планировочная организация национальных парков }
$$

В.А. Клюшин, И.Ф. Михайлова. Москва : ЦНТИ, 1976. 55 с. 
основних елементів: лінійні (природні осі) - річки, прибережні смуги водойм, гірські хребти, а також транспортні магістралі, що перетинають парки, пішохідні і паркові дороги; точкові - населені пункти, виробничі комплекси тощо 16 .

Планувальна організація національних парків - це зумовлене природними факторами функціональне зонування ї території, на основі якого формуються різні типи просторово-планувальних структур, свого роду «каркасів» за напрямами природних осей 3 урахуванням існуючих систем розселення, виробництва, транспорту, інженерних споруд.

За різних природних і соціально-економічних умов планувальна організація національних парків може мати такі планувальні структури (структурні схеми): кільцеву, лінійну, тупикову і комбіновану (рис. 2) ${ }^{17}$.

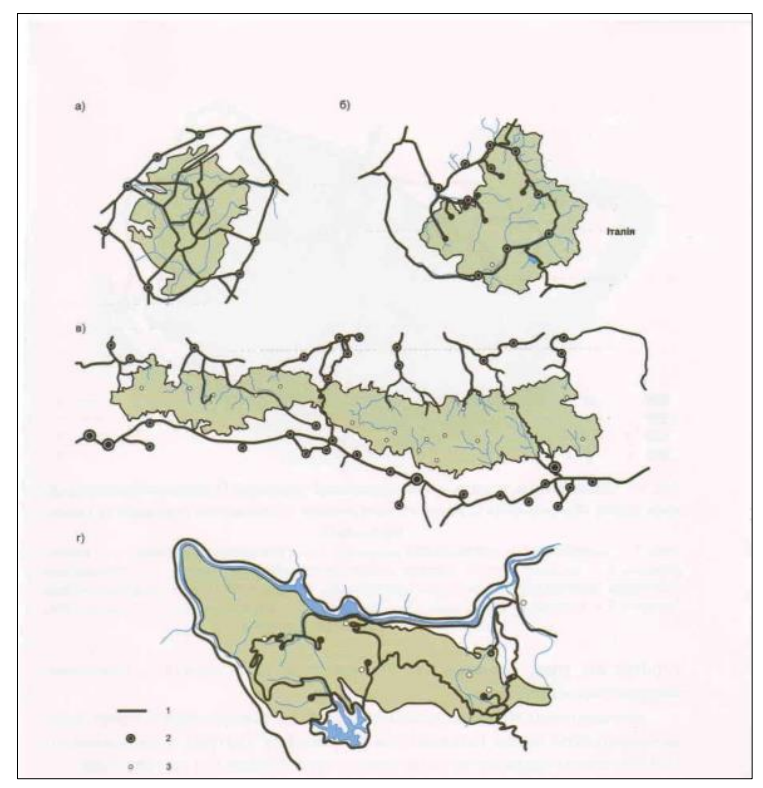

Рис. 2. Схеми планувальної організації території національних парків: а) кільцева (парк «Сімліпал» (Індія); б) тупикова (парк «Вануаз» (Франція); в) лінійна (парк «Централен Балкан» (Болгарія); г) комбінована (парк «Тара» (Сербія). 1 - головні паркові дороги; 2 - населені пункти; 3 - туристичні бази

\footnotetext{
${ }^{16}$ Гродзинський М.Д. Пізнання ландшафту: місце і простір: Монографія. У 2-х т. Київ: ВПЦ «Київський університет», 2005. Т. 1. 431 с.

17 Панченко Т.Ф. Ландшафтно-рекреаційне планування природно-заповідних територій [Монографія]. Київ : Логос, 2015. 176 с.
} 
За кільцевої планувальної структури парку заповідна зона займає центральне положення, рекреаційні - периферійне; за лінійної функціональні зони поступово чергуються вздовж природних осей (приморські, прирічкові райони); за тупикової структури центральне положення займають рекреаційні зони, а заповідна охоплює периферійні території (акваторії) парку (гірські, озерні райони); комбінована планувальна структура об'єднує всі попередні форми (тупиково-кільцева, лінійно-тупикова тощо). Остання $\epsilon$ найбільш поширеною схемою планувальної організації національних парків.

Кільцева планувальна структура характерна для багатьох вітчизняних і зарубіжних національних парків, таких як Карпатський, «Шацький» та «Синевир» (Україна), «Йєллоустонський» (США), «Татранський» (Чехія), «Вітоша» (Болгарія) та інші. За комбінованою схемою здійснена планувальна організація відомих зарубіжних національних парків: «Баварський Ліс» (Німеччина), «Лахемаа» (Естонія), «Аукштайтія» (Литва) тощо ${ }^{18}$.

Значна кількість зарубіжних національних парків створюється на прибережних територіях морів, річок та інших великих водойм зазвичай за лінійною схемою планувальної структури, зокрема: Прибайкальський (Росія), Метропарк (США), Гауя (Латвія), Куршська коса (Литва) тощо ${ }^{19}$.

За комбінованою схемою організована планувальна структура національного парку "Рyrenees" (Франція), який розміщений вздовж гірського хребта вузькою смугою шириною від 1,5 до 20 км. У цьому парку 44\% загальної кількості місць для відпочинку належить стаціонарним закладам (готелі, туристичні притулки), а 64\% відповідно пристосованим оселям місцевих жителів. Цей національний парк міг би прислужитися прикладом для наших вітчизняних парків, які могли б мати на балансі свої стаціонарні рекреаційні об'єкти типу вище названих, а також інтенсивно використовувати можливості сільського зеленого туризму (садиби сільських жителів).

Важливе місце під час розробки планувальної організації (функціонального районування території) НПП України у проектах організації території, охорони, відтворення та рекреаційного використання їх природних комплексів і об'єктів посідає врахування допустимих антропогенних (рекреаційних) навантажень, рекреаційних потреб населення, кількості населених пунктів в регіоні тощо.

Попередньо зазначимо, що рекреаційне навантаження - це агрегатний показник антропогенного впливу (протягом комфортного періоду), що віддзеркалюється кількістю відпочивальників на одиниці

18 Панченко Т.Ф. Ландшафтно-рекреаційне планування природно-заповідних територій [Монографія]. Київ : Логос, 2015. 176 с.

19 Методические рекомендации по архитектурно-планировочной организации природных парков Украинской ССР. Київ : КиевНИИПград, 1978. 89 с. 
площі, часом їх перебування на об'єкті рекреації і видом відпочинку. На цей час для території НПП України загалом запропоновано орієнтовні нормативи допустимого рекреаційного навантаження 1 люд.-день/га, а конкретно для зони регульованої рекреації - близько 5 люд.-день/га, стаціонарної рекреації - 20-50 люд.-день/га ${ }^{20}$.

Для американських національних парків чинні нормативи допустимих рекреаційних навантажень на 1 га значно вищі і становлять від 35 до 60 людей, що пояснюється набагато досконалішим рекреаційним облаштуванням (інфраструктурою - асфальтовані дороги, готелі, кемпінги тощо).

Для забезпечення функціонування національного природного парку формують оптимальну для його території систему транспортних комунікацій, яка охоплює: паркові автодороги - парквеї (для екскурсійно-туристського обслуговування), режимні дороги (для утримання заповідних зон, проведення науково-дослідних робіт, екологічного контролю за станом та режимом природно-заповідних територій), рекреаційно-господарські дороги (для функціонування відповідних об'єктів), зовнішні автодороги (для зв'язку національного парку з іншими поселеннями) тощо.

Щільність автодорожньої мережі рекомендовано брати в середньому $0,2-0,25$ км/км² для парку загалом. Окремо, наприклад, для зони стаціонарної рекреації вона може становити від 2,0 до 5,0 км/км².

Мережа доріг і стежок національного парку повинна відповідати вимогам створення пішохідних, кінних, велосипедних туристичних маршрутів. Щільність цієї мережі рекомендовано в середньому 0,30,6 км/км². Оптимальний норматив iї площі - 5-6\% рекреаційної території парку ${ }^{21}$.

У національних парках туристичні пішохідні маршрути бувають: прогулянкові (в обидва кінці) - до 7 км протягом 2 годин; пізнавальні, одноденні - до 18 км протягом 8 годин; пізнавальні, триденні - до 40 км протягом 20 годин; туристично-тематичні, багатоденні - до 75 км протягом 40 годин; туристично-спортивні, багатоденні - до 130 км протягом 48 годин ${ }^{22}$.

Загалом для регулювання (просторового обмеження) величини рекреаційного навантаження у вітчизняних НПП вздовж трас туристичних маршрутів та екологічних стежок доцільно влаштовувати природозахисні лінійні коридори шириною до 20 м, які повинні

20 Гетьман В.І. Методичні рекомендації щодо визначення рекреаційних навантажень у межах природно-заповідних територій та об'єктів. Полтава: «Дивосвіт», 2017. 43 с.

${ }^{21}$ Шищенко П.Г. Прикладная физическая география. Київ : Вища шк. Головное ид-во. 1988. 192 с.

Гетьман В.I. Методичні рекомендації щодо визначення рекреаційних навантажень у межах природно-заповідних територій та об'єктів. Полтава: «Дивосвіт», 2017. 43 с. 
стримувати вільне пересування відвідувачів парку поза туристською трасою чи екскурсійною (прогулянковою) стежкою. У межах національних парків відповідно до проектів організації ї території можуть прокладатись ландшафтно-маршрутні коридори вздовж туристських трас, які зв'язують рекреаційні центри і становлять собою залежно від рельєфу місцевості лінійні природні урочища шириною від 10 м до 10 км$^{23}$.

На закінчення зазначимо, що функціональне зонування території НПП правомірно розуміти як форму його територіальної організації, або територіального планування. Останнє як галузь науково-практичної діяльності у різних країнах має різні офіційні назви: ландшафтне планування (Німеччина), краєвлаштування (Литва), просторове планування (США), фізичне планування (Голландія) тощо.

Територіальне планування (організація) полягає в обгрунтуванні такого впорядкування ландшафту (влаштування території ландшафту), за якого створюється конфігурація його територіальних елементів (місць, плям), що забезпечує максимально ефективне виконання заданих функцій.

\section{ВИСНОВКИ}

Під функціональним зонуванням розуміють розділення природнозаповідних територій та об'єктів на ділянки (зони) з різними режимами збереження, відтворення і використання ландшафтних (природних) комплексів.

Функціональне зонування національного парку $\epsilon$ головною передумовою його розвитку, гарантією якісного збереження біорізноманіття та раціонального, екологічно зорієнтованого природокористування.

Результатом функціонального зонування території національного парку виступає схема (картосхема) як наочне відображення просторових функцій, які ця територія має виконувати.

На особливостях функціонального зонування національного парку, а також на основі територіальної конфігурації ландшафтних місць базується їх планувальна організація. Вона складається з планувальної структури і функціонального зонування території.

Планувальна організація національних природних парків - це зумовлене природними факторами функціональне зонування їх території, на основі якого формуються різні типи просторовопланувальних структур - кільцева, лінійна, тупикова і комбінована.

23 Гетьман В.I. Методичні рекомендації щодо визначення рекреаційних навантажень у межах природно-заповідних територій та об'єктів. Полтава: «Дивосвіт», 2017. 43 с. 
Важливе місце під час розробки планувальної організації (функціонального районування території) національних природних парків України у проектах організації території, охорони, відтворення та рекреаційного використання їх природних комплексів і об’єктів посідає врахування допустимих рекреаційних навантажень. Для регулювання (просторового обмеження) величини рекреаційного навантаження у вітчизняних НПП вздовж трас туристичних маршрутів та екологічних стежок доцільно влаштовувати природозахисні лінійні коридори.

\section{АНОТАЦІЯ}

Розглянута сутність функціонального зонування територій національних природних парків України і національних парків світу як ключової проблеми їх територіальної організації або планування. У порівняльному аналізі показані як позитивні явища, так і недоліки вітчизняного і світового природоохоронного планування передусім рекреаційних територій.

В Україні існує певний досвід проведення поліфункціонального зонування територій національних природних парків. Однак у літературних джерелах ще відсутні достатньо науково обгрунтовані методичні рекомендації щодо виділення функціональних зон, їх оптимальних площ, конфігурацій, допустимих антропогенних (рекреаційних) навантажень на ділянки природно-заповідних територій та об’єктів.

Практичний досвід створення та діяльності НПП України переконує, що проблема планування їх території має принципово важливе значення. Її практичне вирішення є основною передумовою забезпечення врівноваженого і безконфліктного функціонування цих поліфункціональних природно-заповідних установ.

Підняте питання про рекреаційні навантаження у межах вітчизняних i зарубіжних національних (природних) парків i ïx нормативів.

\section{ЛIТЕРАТУРА}

1. Андрієнко Т.Л. Система категорій природно-заповідного фонду України та питання iii оптимізації / Т.Л. Андрієнко, В.А. Онищенко, М.Л. Клєстов, О.І. Прядко, Р.Я. Арап. Київ : Фітосоціоцентр, 2001. 60 с.

2. Архитектурно-планировочная организация национальных парков / В.А. Клюшин, И.Ф. Михайлова. Москва : ЦНТИ, 1976. 55 с.

3. Гетьман B.I. Національні природні парки України. Київ : Редакція газет природничо-математичного циклу. 2012. (Бібліотека «Шкільного світу»). 128 с. 
4. Гетьман B.I. Методичні рекомендації щодо визначення рекреаційних навантажень у межах природно-заповідних територій та об’єктів. Полтава : «Дивосвіт», 2017. 43 с.

5. Гродзинський М.Д. Пізнання ландшафту: місце i простір: Монографія. У 2-х т. Київ : ВПЦ «Київський університет», 2005. Т. 1. $431 \mathrm{c}$.

6. Забелина Н.М. Национальный парк. Москва : Мысль, 1987. 175 с.

7. Заповідна справа в Україні / Під загальною редакцією М.Д. Гродзинського і М.П. Стеценка. Київ : Географіка, 2003. 306 с.

8. Заповідники і національні природні парки України. Київ : Вища школа, 1999. 232 с.

9. Менеджмент охоронних лісів України / Під загальною редакцією акад. НАН України Шеляга-Сосонко Ю.Р. Київ : Фітосоціоцентр, 2003. 299 c.

10. Методические рекомендации по архитектурно-планировочной организации природных парков Украинской ССР. Київ : КиевНИИПград, 1978. 89 с.

11. Методичні рекомендації щодо складу та змісту проекту організації території національного природного парку, охорони, відтворення та рекреаційного використання його природних комплексів і об’єктів. Київ : Центр екомоніторингу України, 2005. 95 с.

12. Национальные парки в Польше. Варшава : Шевелье, 1989. 16 с.

13. Панченко Т.Ф. Ландшафтно-рекреаційне планування природнозаповідних територій [Монографія]. Київ : Логос, 2015. 176 с.

14. Попович С.Ю. Природно-заповідна справа : навчальний посібник. Київ : Арістей, 2007. 480 с.

15.Природно-заповідний фонд України загальнодержавного значення. Довідник. Київ : Омега-Л, 1999. 240 с.

16. Проект організації території національного природного парку «Синевир», охорони, відтворення та рекреаційного використання його природних комплексів і об'єктів, затверджений наказом Міністерства екології та природних ресурсів України від 27 березня 2003 р. № 47/ДС.

17. Шищенко П.Г. Прикладная физическая география. Київ : Вища шк. Головное ид-во. 1988. 192 с.

18. Global ecology: A New Arena of Political Conflicts / Ed. By W. Sachs. - London; New Jersy, 1993. 262 p.

\section{Information about author:} Getman V. I.

Candidate of Geographic Sciences, Associate Professor, Associate Professor of the Department of Protected Areas State Ecological Academy of the Ministry of Energy and Environmental Protection of Ukraine 35, Metropolit Vasily Lipkivsky str., building 2, Kyiv, 03035, Ukraine 